\title{
iER日MF
}

\section{The Desain of Hospitality and Tourism Development in Cirebon - West Java, Indonesia: Need Synergy among Local Wisdom economic-Religion}

\author{
Abdul Nasir ${ }^{1}$, Waridin Waridin ${ }^{2}$ Deden Dinar Iskandar ${ }^{2}$ and Indah Susilowati ${ }^{2}$ \\ 1/ Ph.D. student, at the Faculty of Economics and Business, Diponegoro University ${ }^{2 /}$ Lecturer at the Faculty of \\ Economics and Business, Diponegoro University
}

\begin{abstract}
The city of Cirebon lies in the coastal of North-east of West Java corner. It is bordered with Central Java Province. Cirebon is also called as "Kota Udang", means that city of shrimp. The history recorded that the Sultanate of Cirebon was an Islamic sultanate in West Java founded in the 15th century. Therefore, nowadays Cirebon popular for religion-tourism destination besides culinarytourism and batik Cirebon. As of now, Cirebon has many potential culinary-tourism, among others are: dinning dish with local recipes such as "empal genthong", local beverage of "tape ketan", preserved sea food such as "trasi", etc.

Economic valuation of CVM with hypothetical market approach was applied to design religionculinary tourism development of Cirebon. Descriptive statistics and transaction cost were also invoked to analyses the data. Further, Mixed method was also applied to this study. Several desain of religion-and-culinary tourism of Cirebon have been developed. Which and which desain(s) will be suitably implemented with the ultimate goal of welfare betterment for the people of Cirebon, then need try out and further confirmation from the competent stakeholders involved as the best model.
\end{abstract}

Key-words: tourism, religion, culinary, desain, welfare, Cirebon, Indonesia. 